\title{
MELACAK PRAKTIK COPY PASTE MAKALAH TEKNOLOGI INFORMASI DAN KOMUNIKASI DARI INTERNET DI KALANGAN MAHASISWA FUAD IAIN PONTIANAK
}

\author{
Syarifah Fatimah
}

\begin{abstract}
Abstrak
Makalah di tengah mahasiswa IAIN Pontianak merupakan hal biasa. Di setiap semester mereka akan menemukan tugas penulisan makalah. Suatu hal disesalkan kebanyakan makalah telah dibuat melalui praktik copy paste. Praktik demikian itu terbukti dalam studi penelitian pada makalah Teknologi Informasi dan Komunikasi mahasiswa FUAD IAIN Pontianak. Secara umum, ada dua tipe praktik copy paste. Pertama, praktik copy paste secara utuh dari sumber internet. Kedua, praktik copy paste dengan modifikasi dari gabungan sejumlah makalah. Hal demikian itu disimpulkan setelah diadakan penelitian dengan menggunakan aplikasi Duplichecker dan Plag Tracker. Sistem aplikasi tersebut mampu membongkar makalah hasil modifikasi. Pada umumnya, mahasiswa FUAD mengambil makalah untuk di copy paste dari sumber blog di internet. Blog-blog tersebut menjadi ladang bagi pengunduhan makalah untuk di-copy paste.
\end{abstract}

Kata kunci: makalah mahasiswa, copy paste, internet.

\section{A. Pendahuluan}

Internet di era teknologi informasi dan komunikasi menjadi suatu kebutuhan yang tidak dapat tergantikan, terutama bagi kalangan profesional. Di hampir semua perkantoran, internet selalu ditemukan, mulai perbankan, pemerintahan, sampai lembaga perguruan tinggi. Internet telah terbukti memberikan manfaat bagi sejumlah institusi tersebut, mulai keperluan administrasi, birokrasi, informasi, komunikasi, transaksi, sampai proses pembelajaran. Mereka tidak dapat mengingkari nilai manfaat internet, kecuali berada di tepi zaman.

Di tengah lingkungan perguruan tinggi, internet digunakan untuk kepentingan administrasi, informasi, komunikasi, dan transaksi, termasuk di dalamnya sistem informasi akademik. Pada gilirannya, karyawan, dosen, dan mahasiswa di suatu kampus mulai bergantung dengan sistem komputer berjaringan tersebut, karena banyak hal terkait urusan mereka ditentukan dan terkait layanan internet. Pada batas itu, 
internet mengubah tradisi kerja masyarakat di lingkungan perguruan tinggi, baik negeri maupun swasta. Mereka tidak lagi menggunakan cara konvensional, karena banyak hal berbasis internet.

Sementara itu, internet bagi kalangan mahasiswa memiliki nilai manfaat tersendiri, yaitu ruang pencarian informasi dan pengetahuan atau literatur akademis. Hal itu dikarenakan mahasiswa tidak cukup hanya bersandar pada ceramah dosen dalam perkuliahan di kelas. Mereka memerlukan materi tambahan lain, terutama untuk menyelesaikan tugas-tugas kuliah. Di era ini, informasi dan pengetahuan atau literatur akademis terasa mudah dan cukup banyak ditemukan di internet. Pada gilirannya, mahasiswa lalu memanfaatkan internet untuk mencari situs-situs dengan konten informasi dan pengetahuan atau literatur akademis.

Di dalam kontek itu, muncul praktik copy paste dalam laporan tugastugas mahasiswa, bukan hal baru, melainkan telah mentradisi, karena telah dimulai dari tahun-tahun silam. Praktik demikian itu bukan hal rahasia, karena diketahui banyak dosen, bahkan telah dijadikan objek penelitian di IAIN Pontianak. ${ }^{1} \mathrm{Di}$ tengah mahasiswa dan

\footnotetext{
1 Lihat Firdaus Achmad, Fenomena Copy Paste di Lingkungan Mahasiswa: Refleksi Interpretatif Atas Ekspektasi Belajar Mahasiswa IAIN Pontianak, Laporan
}

dosen, praktik copy paste diakui sebagai bentuk penyimpangan terhadap nilai-nilai keilmuan, tetapi karena telah mentradisi, maka praktik tersebut sulit untuk disingkirkan dari ruang kelas.

Secara etika keilmuan, tradisi copy paste adalah kebiasaan tidak baik atau buruk yang harus segera ditinggalkan setiap mahasiswa dan dicegah dosen, karena berakibat pada kebodohan dan kebobrokan mental. Para dosen harus mampu mengembalikan mahasiswa kepada tradisi akademis yang cerdas.

\section{B. Fasilitas Copy Paste Pada Komputer \\ Istilah copy paste di tengah} kalangan mahasiswa, dosen, pegawai perkantoran telah dikenal cukup populer. Istilah tersebut sering dipakai di banyak tempat perbincangan, tidak hanya terselip dalam teks-tulisan. Meskipun demikian, suatu hal cukup unik, copy paste terasa sulit untuk didefinisikan secara tepat oleh para penuturnya. Mereka mampu memahami istilah tersebut dalam suatu komunikasi, tetapi mereka kurang mampu merumuskan definisinya.

Di dalam penelitiannya, Firdaus Achmad tidak memberikan definisi

Penelitian Kompetitif Individual IAIN Pontianak, 2015. 
tentang istilah copy paste. Istilah tersebut terkesan dibiarkan terpahami secara adanya. Namun, copy paste di dalam penelitian itu dipahami semakna dengan istilah plagiat, karena kedua istilah tersebut sering digunakan untuk saling ganti-menggantikan. Sementara, istilah plagiat dalam KBBI memiliki pengertian sebagai perbuatan pengambilan karangan (pendapat, dII) milik orang lain, lalu dijadikan seolaholah miliknya. Istilah plagiat di kamus itu disepadankan dengan jiplak. Pada batas itu, istilah plagiat digunakan Firdaus Achmad untuk mengartikan istilah copy paste.

Pada asalnya, istilah copy paste adalah gabungan dua kata, copy dan paste. Di dalam kontek ini, istilah itu muncul dalam tampilan sub menu program pengolahan kata atau program microsoft office, seperti word, excel, dan access. Sub menu copy digunakan untuk menggandakan atau menduplikat suatu tulisan dan pelbagai hal, seperti file dan folder. Sedangkan, paste adalah sub menu untuk menampilkan hasil duplikasi.

Sedangkan, istilah copy paste di dalam kontek tulisan ini dipahami sebagaimana makna dalam penggunaannya di tengah mahasiswa, yakni tindakan duplikasi atau penjiplakan suatu tulisan milik orang lain di internet, sehingga dalam kontek tersebut memiliki pengertian plagiat.

Di dalam sejumlah kepentingan, terkait penggunaan komputer, copy paste sering dipraktikan untuk mempersingkat suatu pekerjaan terkait dengan penggandaan atau hal sejenisnya. Fasilitas copy paste sangat bermanfaat, tanpanya banyak pekerjaan di depan komputer akan terasa sulit, bahkan menyusahkan pengguna, karena detail-detail pekerjaan terkadang memerlukan ketelitian dan banyak menghabiskan waktu. Hal demikian itu terasa bagi banyak kalangan, terutama administrasi, pengolahan data, atau programer komputer.

Secara ideal, fasilitas copy paste digunakan untuk kepentingan sebagaimana disebutkan di atas. Pada prinsipnya, fasilitas dalam suatu program didesain memang untuk kepentingan dan layanan kemudahan bagi pengguna, bukan selainnya. Demikian itu prinsip kerja yang dihadirkan komputer. Semua akan diberikan dalam rangka memberikan kemudahan bagi pengguna, sehingga setiap tahun akan muncul pelbagai perbaikan ke arah penyempurnaan.

\section{Internet Sebagai Ruang Penyedia Informasi}

Secara sederhana, teknologi internet diartikan sebagai jaringan 
komputer internasional, karena tiap komputer memiliki saling keterhubungan dalam suatu sistem. Internet atau interconetion networking merupakan hasil perkembangan teknologi di bidang komputer dan komunikasi. Sementara, kabel, serat optik, dan satelit merupakan media komunikasi yang menghubungkan tiap-tiap komputer dalam sebuah bangunan internet. Keberadaan internet tersebut, terutama terkait masalah masa depan (era globalisasi) zaman di mana semua orang atau masyarakat tidak bisa lepas dari informasi. Di era itu, informasi merupakan suatu kebutuhan yang sangat urgen, hingga dikenal satu pendapat "Siapa yang menguasai informasi, maka menguasai dunia". Jaringan internet di dalam pengelolaannya ditangani komunitas Internet Society. Mereka merupakan suatu komunitas internasional yang berorientasi pada layanan masyarakat, nirlaba, dan profesional. Sedangkan, masalah desain atau evolusi arsitektur dan pengoperasian internet ditangani The Internet Engineering Task Force. Mereka adalah suatu komunitas internasional, terdiri para perancang jaringan, operator, penjual, dan peneliti keilmuan. $^{2}$

2 Internet bermula dengan adanya proyek sistem Arpanet (Advanced Research Project Agency) yang dibangun tahun 1946 di Amerika Serikat, yang mana pada saat itu diawali dengan keterhubungan 4
Pada prinsipnya, internet merupakan sebuah ruangan dunia maya yang berisi milyaran lembaran kosong yang terbuka untuk diunggah dengan pelbagai oleh para pengguna internet. Isi internet menjadi sangat beragam sebanyak dan serumit realitas kehidupan nyata manusia, bahkan lebih komplek, karena di ruang internet ada potensi rekayasa. Segala sesuatu di hamparan realitas nyata dapat diunggah ke dalam internet, tentu melalui proses elektronis atau digital. Internet merupakan dunia maya terbentuk atau hasil duplikasi realitas nyata.

Proses transformasi di atas biasa dikenal dengan istilah pengunggahan, terambil dari asal kata unggah, berarti proses pemindahan data elektronik antarkomputer atau sistem serupa lainnya, biasa dikenal dengan istilah upload. Pengunggahan secara teknis terhitung mudah, karena tidak melalui proses yang rumit atau bertele-tele. Setiap pengguna komputer hampir dapat dipastikan mampu mengoperasikan cara pengunggahan sesuatu data elektronis ke ruang internet. Di dalamnya tidak ada aturan dan beban pembiayaan. ${ }^{3}$

jaringan universitas di antaranya, Utah dan Cambridge University.

3 Meskipun demikian, perbuatan-perbuatan terkait dengan penggunaan internet yang memiliki unsur pidana dapat dikenai pasal UU ITE, seperti pornografi, pencemaran nama baik, dan penipuan. 
Pada batas itu, internet menjadi penuh berisi dengan pelbagai informasi. Di setiap hari, informasi selalu diunggah untuk diperbarui, hingga segalanya hampir serba ada, terukur dari banyaknya rasa keingintahuan masyarakat yang terpenuhi oleh internet. Hal demikian itu berlangsung tanpa kontrol dari siapa atau lembaga apa pun, termasuk negara. Mereka hanya dapat menutup situs dengan teknik tertentu, tidak dapat mengendalikannya.

\section{Persebaran Makalah di Internet}

Makalah dalam KBBI diartikan sebagai tulisan tentang suatu pokok yang dimaksudkan untuk dibacakan di muka umum dalam suatu persedingan dan yang sering diterbitkan. Selain arti itu, KBBI juga mengartikan makalah sebagai karya tulis pelajar atau mahasiswa sebagai laporan hasil pelaksanaan sekolah atau perguruan tinggi.

Secara umum, istilah makalah di tengah kalangan mahasiswa dipahami sebagai suatu karya ilmiah tentang suatu masalah yang biasanya dikumpulkan atau dipresentasikan di kelas untuk didiskusikan bersama, termasuk dengan dosen. Istilah karya ilmiah tersebut memberikan suatu batasan atau ketentuan suatu tulisan makalah, berupa sejumlah kaidah dan sekaligus etika keilmuan. Di antaranya terpenting adalah sumber rujukan atau literatur keilmuan penulisan makalah yang menjadi sandaran dan dasar bagi pikiran dalam tulisan makalah. Sedangkan, hal lainnya terkait dengan ketentuan teknik penulisan, baik dalam format penyusunan maupun penggunaan bahasa dan teknik penulisan. Di tengah mahasiswa, makalah secara umum dipahami dalam pengertian tersebut.

Di era digital, proses penulisan suatu makalah dirasa mudah di kalangan mahasiswa, bahkan dalam proses penyimpanan. Mereka dimudahkan dengan adanya teknologi komputer. Hal demikian itu tentu sangat berbeda ketika mahasiswa tahun 1980-an yang dalam pembuatan makalah bergantung pada mesin ketik. Pembuatan makalah dirasa cukup sulit dalam teknik penulisannya. Sementara, penulisan suatu makalah dengan komputer terasa mudah dibuat, diubah, disalin, disimpan, digandakan, dan dipindahkan dari satu komputer ke komputer lain atau ke suatu sistem elektronis lain.

Pada gilirannya, ketika teknologi informasi memperkenalkan aplikasi blog atau website, muncul trend di kalangan mahasiswa untuk mengunggah karya makalahnya ke internet. Secara sederhana, blog adalah sejenis aplikasi web. Secara teoritik, blog merupakan 
bagian dari temuan atau turunan website yang di dalamnya dapat juga dimuat tulisan, gambar, dan video. Blog didesain penemunya sebagai media publikasi guna menyampaikan karya-karya pribadi, termasuk makalah. Pada batas itu, suatu makalah memungkinkan untuk dibaca dan diunduh pengguna komputer yang berada di pelbagai tempat.

Makalah di dalam kontek itu ditemukan banyak beredar di dunia maya. Blog menjadi aplikasi web pilihan untuk menampilkan makalah di internet. Banyak mahasiswa yang mengisi ruang blognya dengan karya makalah yang dibuatnya untuk memenuhi tugas belajar di kelas. Makalah tidak lagi tersimpan rahasia di suatu komputer atau flashdisc. Proses pengunggahan makalah dari komputer ke ruang internet terhitung cukup mudah, sehingga trend tersebut terus meningkat di kalangan mahasiswa, tidak ada batasan pada jurusan atau fakultas atau suatu perguruan tinggi tertentu. Sebagai akibatnya, makalah berisi pelbagai pengetahuan dan disiplin ilmu cukup mudah ditemukan di internet.

\section{E. Praktik Copy Paste Makalah Teknologi Informasi dan Komunikasi dari Internet Mahasiswa FUAD IAIN Pontianak}

Mahasiswa IAIN Pontianak di dalam proses pembelajaran terhitung biasa untuk tugas penulisan makalah. Di banyak mata kuliah, mereka dibebani untuk menulis, mengumpulkan, dan mempresentasikan satu judul makalah di ruang kelas. Makalah biasa dibuat secara kelompok kecil, lalu disajikan di ruang kelas untuk didiskusikan, terkadang secara individual untuk tugas rumah. Tugas penulisan makalah biasa dimulai sejak mahasiswa berada di semester I. Mereka dibebani tugas tersebut untuk peroleh nilai, bagian dari akumulasi nilai akhir kuliah, sehingga makalah dirasa sebagai kewajiban.

Hal sama pada mata kuliah Teknologi Informasi dan Komunikasi (TIK) di Fakultas Ushuludin, Adab, dan Dakwah IAIN Pontianak. Mata kuliah tersebut diberikan kepada mahasiswa pada semester II dan III. Setiap mahasiswa jurusan di FUAD dibebani dengan mata kuliah TIK, karena nilai pentingnya bidang keilmuan tersebut bagi mahasiswa, terlebih lagi sebagai calon sarjana bidang dakwah. Di mata kuliah itu, setiap kelas terbagi ke dalam beberapa kelompok kecil untuk ditugasi membuat suatu makalah dengan tema tertentu sesuai silabus, lalu dipresentasikan di ruang kelas. Sementara, satu makalah diserahkan kepada dosen untuk diberi penilaian tersendiri. Pada saat sama, makalah itu disajikan di hadapan ruang kelas lalu didiskusikan bersama-sama. Pada 
bagian akhirnya, dosen pengampu mata kuliah akan memberikan penjelasan terkait sejumlah point penting dalam diskusi dan sekaligus pendalaman materi.

Suatu hal menarik bahwa mahasiswa FUAD ternyata tidak sepenuhnya menulis makalah TIK secara bertanggung jawab. Mereka di dalam kepentingan praktis telah melakukan plagiat melalui praktik copy paste. Makalah yang secara ideal harus ditulis sebagai karya pribadi terabaikan, karena digantikan dengan makalah karya orang lain. Hal demikian itu didasarkan pada penelitian pada makalah-makalah mereka yang dikumpulkan kepada dosen. Di tangan dosen, makalah mahasiswa dinilai dari pelbagai segi, meliputi substansi penulisan, teknis, dan terpenting orisinilitas makalah. Pada batas orisiniltas itu, makalah mahasiswa selalu tidak memiliki nilai, karena hasil praktik copy paste. $^{4}$

Tabel I: Sampel Makalah

\begin{tabular}{|c|c|c|c|c|}
\hline \multirow{2}{*}{ No. } & $\begin{array}{c}\text { Nama } \\
\text { Jurusan }\end{array}$ & Kelas & $\begin{array}{c}\text { Distribusi } \\
\text { Mata } \\
\text { Kuliah TIK }\end{array}$ & $\begin{array}{c}\text { Sample } \\
\text { Makalah }\end{array}$ \\
\hline 01 & KPI & $\mathrm{A}$ & $\mathrm{II}$ & 5 \\
\cline { 3 - 5 } & & $\mathrm{B}$ & $\mathrm{II}$ & 5 \\
\hline 02 & $\mathrm{BKI}$ & $\mathrm{A}$ & $\mathrm{III}$ & 5 \\
\hline 03 & $\mathrm{MD}$ & $\mathrm{A}$ & $\mathrm{III}$ & 5 \\
\cline { 2 - 5 } & & $\mathrm{B}$ & $\mathrm{III}$ & 5 \\
\hline 04 & $\mathrm{IAT}$ & $\mathrm{A}$ & $\mathrm{I}$ & 5 \\
\hline 05 & PA & $\mathrm{A}$ & 0 & 0 \\
\hline \multicolumn{2}{|c|}{ Total Makalah Untuk Sampel Penelitian } & 30 \\
\hline
\end{tabular}

4 Sebagai akibatnya, teknis dan subtsansi penulisan tidak lagi dinilai, karena bukan karya mahasiswa. Pada batas itu, mereka tidak peroleh nilai dari hasil makalah yang dikumpulkan.
Makalah di atas setelah diteliti secara detail dapat diklasifikasikan ke dalam beberapa model praktik copy paste. Pertama, makalah hasil copy paste dari satu sumber dengan format sama. Makalah model tersebut diunduh dari internet secara adanya, lalu dicetak ulang dalam bentuk hard copy. Kedua, makalah hasil copy paste dari beberapa sumber dengan modifikasi struktur penulisan, sehingga menghasilkan format beda atau baru. Pada prinsipnya, kedua klasifikasi model makalah tersebut secara $80 \%$ adalah produk copy paste.

Suatu hal diakui bahwa ada pada bagian tertentu makalah yang tidak hasil copy paste dari internet. Hal tersebut ditemui secara umum pada makalah mahasiswa. Mahasiswa di bagian bab pendahuluan dan penutup makalah tidak melakukan praktik copy paste. Mereka biasa membuat tulisan tersendiri dalam kedua bab tersebut untuk disesuaikan dengan kontek FUAD IAIN Pontianak. Di batas itu, bagian makalah TIK mahasiswa FUAD bukan hasil praktik copy paste. Padahal, bab pendahuluan dan penutup secara substansial bukan bagian dari pokok makalah, melainkan sekedar pengantar dan kesimpulan makalah.

\section{F. Melacak Praktik Copy Paste}

Makalah TIK mahasiswa FUAD secara sederhana dapat diselidiki terkait 
ada atau tidak adanya praktik copy paste melalui mesin pencarian di internet. Proses penelusuran dapat dimulai dengan memasukan kata kunci pada mesin pencari lalu biarkan mesin tersebut mengadakan penelusuran di pelbagai situs. Selanjutnya, mesin pencarian akan memberikan laporan hasil temuan dengan menampilkan kata yang sama dalam jumlah banyak di pelbagai situs. Setelah itu, situs yang memiliki kata sama dapat dibuka untuk diteliti guna menemukan unsur kesamaan antara isi situs dengan makalah mahasiswa TIK. Pada batas itu, makalah TIK mahasiswa FUAD dapat dinilai untuk diperbandingkan, hingga dapat disimpulkan ada atau tidak adanya praktik copy paste.

Cara sederhana di atas pada tingkat tertentu tidak dapat mengidentifikasi praktik copy paste di kalangan mahasiswa ketika makalah dibuat dengan cara memodifikasi makalah dari internet, hingga tersusun struktur makalah baru. Kasus makalah copy paste demikian mengandung kerumitan yang tidak dapat dipecahkan dengan hanya mengandalkan mesin pencarian di internet. Kasus lebih rumit lagi ketika makalah mahasiswa yang tersusun adalah hasil copy paste dari sejumlah makalah, hingga terkesan tidak mengandung unsur plagiat.
Dupli Checker merupakan salah satu aplikasi yang dapat digunakan untuk melacak makalah plagiarisme model praktik copy paste dari situs internet. Pada tahap awal, tulisan makalah diketik ulang lalu dijadikan dalam bentuk file kemudian di-copy untuk di-paste-kan dalam aplikasi Dupli Checker. Selanjutnya, setelah terupload, maka aplikasi tersebut akan mengelola hasil inputan data, hingga akan muncul laporan, berupa informasi plagiarisme. Secara teknis, model aplikasi tersebut hanya dapat bekerja untuk tulisan kurang dari 1000 kata. Pada batas itu, pelacakan plagiarisme harus dilakukan secara bertahap. Seandainya, kata tertulis lebih dari 1000 kata, maka mesin tersebut akan error.

Plag Tracker merupakan mesin pelacak plagiarisme serupa dengan Dupli Cheker. Proses penginputan data di antara kedua mesin tersebut adalah sama. Tulisan makalah diubah menjadi bentuk soft copy kemudian di-paste-kan dalam aplikasi. Di dalam hasilnya, Plag Tracker lebih menghasilkan informasi lebih akurat dan sempurna, karena diikuti dengan petunjuk teknis berupa indikasi plagiarisme. Sejumlah situs yang terdeteksi memiliki konten sama dilaporkan dan diberi skor prosentase kesamaan atau kemiripan, sehingga diketahui relasi antara data yang terinput 


\section{mampu memberikan prosentase}

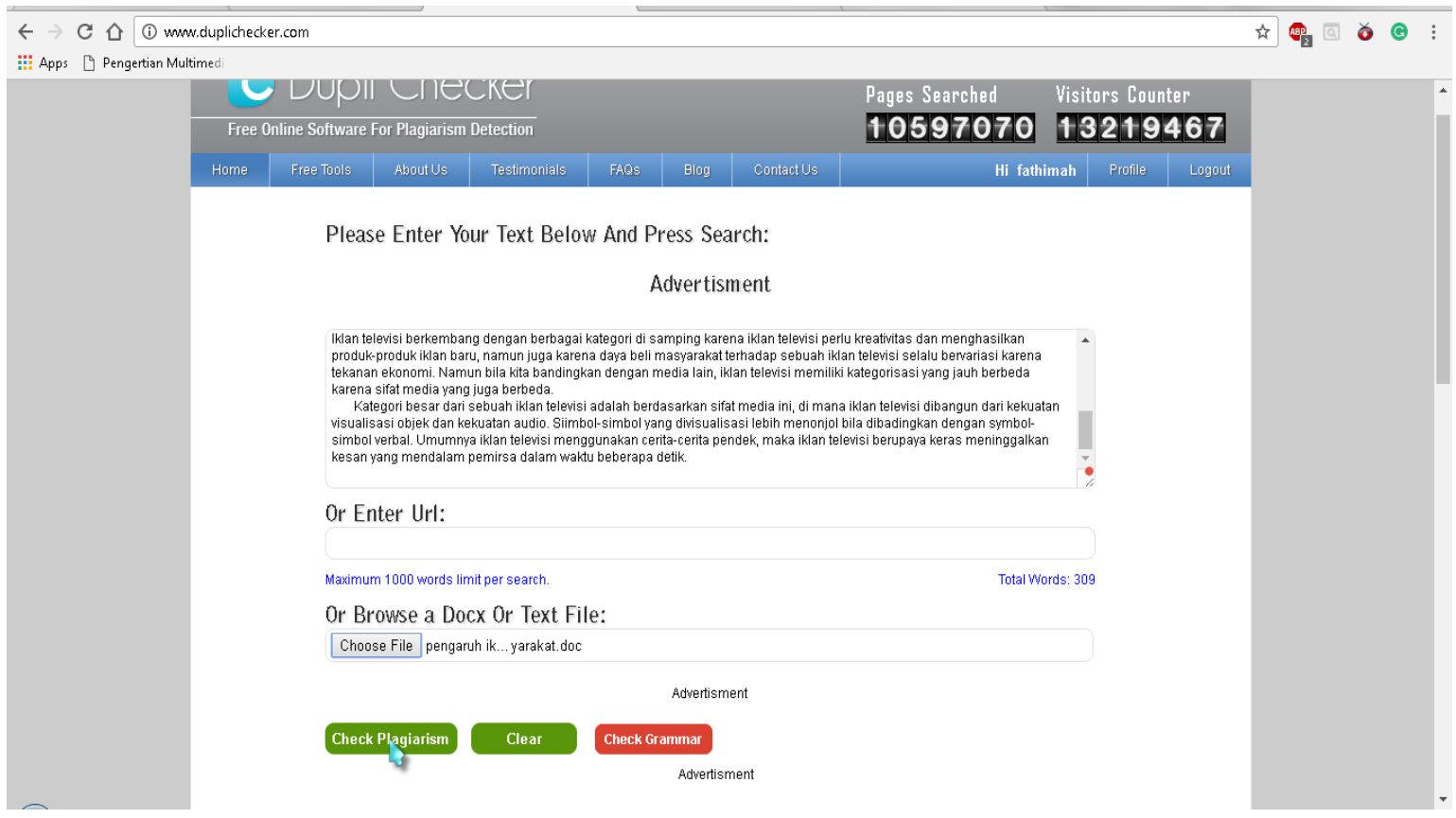

Proses Input Data dari Makalah TIK ke Aplikasi Dupli

Cheker

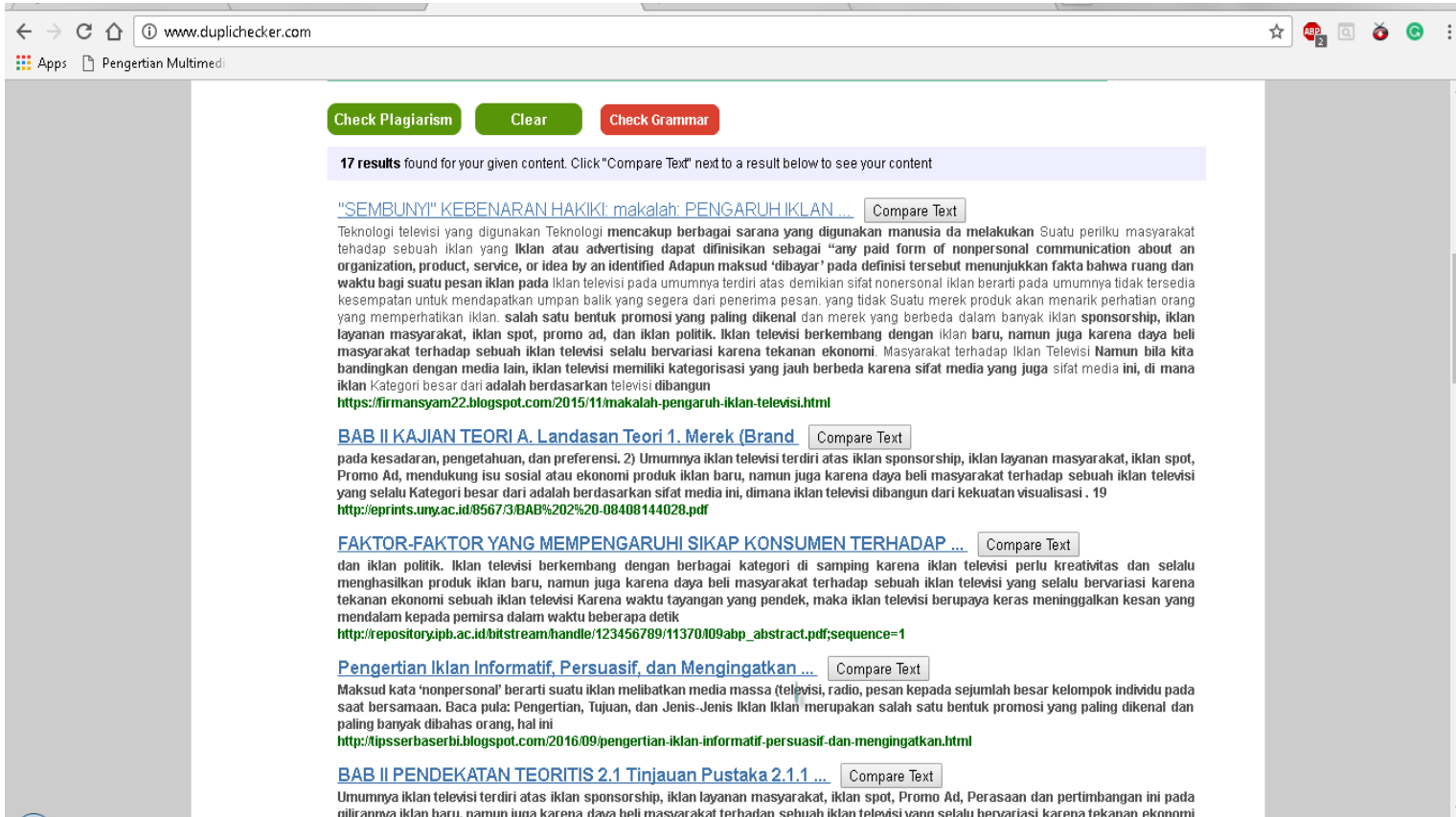




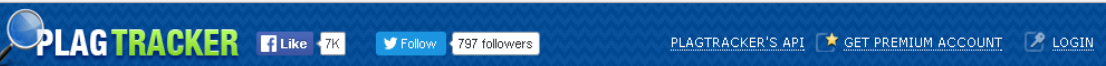

umumnya harus dibeli. Maksud kata 'nonpersonal' berarti suatu iklan melibatkan media massa (televisi, radio, majalah, koran) yang dapat mengirimkan pesan kepada sejumlan besar kelompok individu pada saat bersamaan. Dengan demikian sifat nonersonal iklan berarti pada umumnya tidak tersedia kesempatan untuk mendapatkan umpan balik yan egera dari penerima pesan.

klan merupakan salah satu bentuk promosi yang paling dikenal dan paling banyak dibahas orang. Hal ini kemungkinana karena daya Jangkauannya vang luas. Iklan juga menjadi instrument promosi yang sangat penting khususnya bagi perusahaan yang memproduksi barang atau jasa yang ditujukan kepada masyarakat luas.

Iklan televisi pada umumnya terdiri atas iklan sponsorship, iklan layanan masyarakat, klan spot, promo ad, dan iklan politik. Iklan televisi berkembang dengan berbagai kategori di samping karena iklan televisi perlu kreativitas dan menghasilkan produk-produk iklan baru, namun juga karena daya beli masyarakat terhadap sebuah iklan televisi selalu bervariasi karena tekanan ekonomi. Namun bila kita bandingkan dengan media lain, iklan televis memiliki kategorisasi yang jauh berbeda karena sifat media yang juga berbeda

Kategori besar dari sebuah iklan televisi adalah berdasarkan sifat media ini dimana iklan televisi dibangun dan yang alMsur was klan telensinengyaka keras meninggalkan kesan yang mendalam pernirsa dalam waktu beberapa detik.

Gambar 3

Input Data ke Aplikasi Plag Tracker

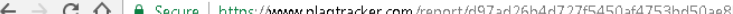

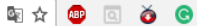
:i: Apps $\square$ Pengertian Multime

Qplagtracker faue ork

Your paper contains $100 \%$ of non-unique content that appears in 5 Sources Please make sure that hightighted text is properly referenced

(-) Our advice

Looks like your paper needs some changes. Let us help you

Live Daily Stats:

Papers checked today:

1871

Average \% of plagiarism:

52

Positive feedback from customers: 150

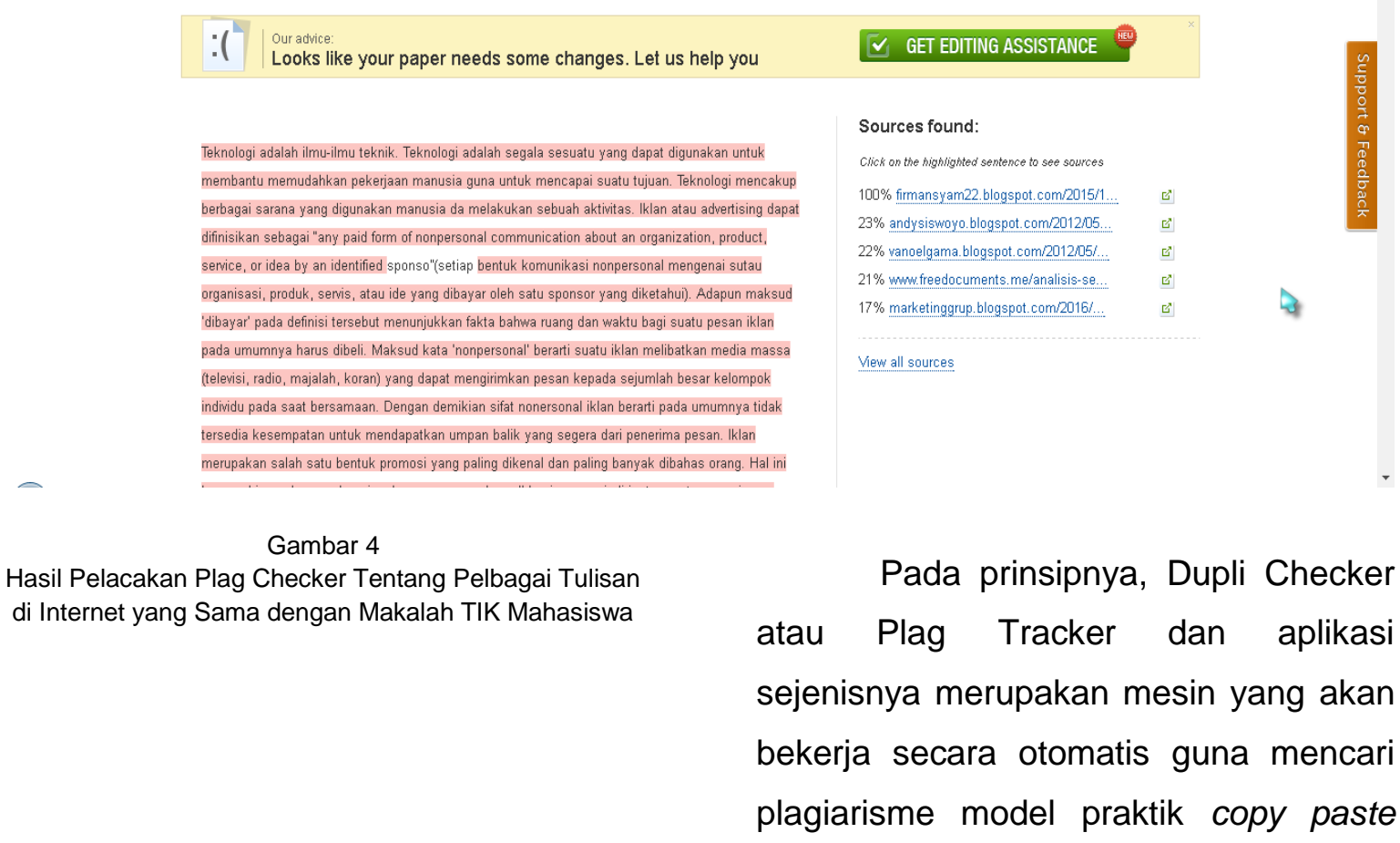


dari situs internet. Mesin tersebut akan bekerja secara mekanis sehingga menghasilkan nilai objektif, berupa kalkulasi prosentase, tidak mengandalkan interpretasi subjektif.

Makalah TIK mahasiswa FUAD

IAIN Pontianak melalui mesin pelacak di atas terbongkar dan diketahui bahwa makalah mereka bukan karya tulis pribadi secara utuh, melainkan hasil praktik copy paste dari situs-situs di internet. Hal ini ditemukan pada hampir semua sampel makalah yang diteliti.

Hasil temuan di atas memberikan informasi bahwa rujukan copy paste di kalangan mahasiswa FUAD bersumber pada makalah-makalah yang diunggah pada situs blog. Di dalam blog tersebut sering ditemukan laman berisi makalah atau kumpulan makalah yang tersaji untuk dibaca dan diunduh pengunjungnya. Secara umum, blog tersebut adalah milik mahasiswa lain. Mereka menulis tugas makalah di lembaga pendidikannya, lalu diunggah ke dalam blognya. Hal itu merupakan maklum, karena fungsi utama blog untuk menuangkan pelbagai hal pemiliknya, termasuk makalah. Namun demikian, sejumlah kasus menunjukan bahwa beberapa blog terdapat makalah yang sama, karena diyakini hasil berbagi dari satu pemilik blog kepada yang lainnya. Praktik demikian biasanya dengan izin pemilik aslinya, sehingga dianggap tidak ada masalah. Blog-blog demikian itu menjadi sumber mahasiswa FUAD untuk mempraktikan copy paste.

\section{Penutup}

Makalah TIK sebagai tugas dari dosen untuk mahasiswa FUAD IAIN Pontianak melalui penelitian singkat di atas terbongkar atau diketahui belum dilaksanakan secara bertanggung jawab. Mereka mengumpulkan makalah yang bukan karya pribadi, karena makalah tersebut adalah hasil praktik copy paste. Isi makalah merupakan hasil pemikiran orang lain, baik secara utuh maupun hasil modifikasi sejumlah makalah. Pada prinsipnya, kebanyakan di antara mereka tidak menghasilkan karya makalah, melainkan sekedar melakukan plagiat.

Praktik copy paste mahasiswa di atas harus segera diakhiri, tidak terbatas pada makalah Teknologi Informasi dan Komunikasi, melainkan semua karya makalah mahasiswa IAIN Pontianak. Praktik copy paste diketahui sejumlah dosen terjadi pada kebanyakan mahasiswa, bukan praktik khas mahasiswa FUAD. Hal demikian dapat dimulai dengan keseriusan dosen untuk menilai makalah dan adanya sanksi tegas pada mahasiswa yang melakukan praktik copy paste. Secara etika keilmuan, praktik demikian itu adalah 
kejahatan ilmiah, sehingga tugas dosen membenahi mentalitas mahasiswa, terbentuk profesionalitas akademis.

Pada tataran institusional, pencegahan terhadap praktik copy paste harus dilakukan secara sistemik. IAIN Pontianak harus mulai mengevaluasi tentang keberadaaan perpustakaan, baik di jurusan, fakultas, dan lembaga IAIN. Buku koleksi perpustakaan harus diukur dalam kemampuannya mendukung dan menopang keperluan mahasiswa di bidang literatur keilmuan. Hal ini menjadi penting karena kelangkaan buku di perpustkaan akan membuat mahasiswa berpaling kepada internet, hingga burujung pada praktik copy paste. Di saat sama IAIN Pontianak harus membuka kerjasama dengan perpustakaan lain di Kota Pontianak dan sekitarnya untuk kepentingan mahasiswa dalam pemenuhan pencarian literatur. Saling kerjasama antarperpustakaan di Pontianak akan memberikan banyak dukungan bagi mahasiswa untuk mengembangkan diri dalam bakat keilmuannya, tidak terbatas dalam pencarian literatur tugas kuliah.

\section{E. Daftar Pustaka}

\section{Buku}

Darma, dkk. Internet. Jakarta: Mediakita, 2009.
Doyle, Stephen. Understanding Information and Communcation Technology. Cheltenham: Stanley Thornes, 2000.

Mantra, Ida Bagoes. Filsafat Penelitian dan Metode Penelitian Sosial, Yogyakarta: Pustaka Pelajar, 2004.

Nawawi, Hadari. Dkk. Metode Penelitian Bidang Sosial, Yogyakarta: Gadjah Mada, 1997.

Sawyer, William. Using Information Technology, English: The McGrawHill, 2007.

Zorkoczy, Peter. Teknologi Informasi, Jakarta: Gramedia, 1998

\section{Penelitian Individual IAIN Pontianak}

Firdaus Achmad, Fenomena Copy Paste di Lingkungan Mahasiswa: Refleksi Interpretatif Atas Ekspektasi Belajar Mahasiswa IAIN Pontianak, tahun 2015.

\section{Kamus}

A Devision of Microsoft Corporation, Computer Dictionary, terj. Margunandi. Jakarta: Elex Media Komputindo, 1995.

Kamus Online KBBI.

https://id.wikipedia.org/wiki/Pengunduha n_dan_pengunggahan (tanggal akses 8 nop 2016. Jam 10.58 wib) www.turnitin.com www.plagtracker.com www.duplichecker.com www.plagiarsmcheckerx.com 